\title{
Antimicrobial susceptibility of bacteria isolated from goats with subclinical mastitis in the Southern Marmara region of Turkey
}

\author{
GULSEN GONCAGUL'1, ELCIN GUNAYDIN², YAVUZ COKAL ${ }^{3}$

\begin{abstract}
${ }^{1}$ Mennan Pasinli Equine Vocational School, Bursa Uludag University, Bursa, Turkey ${ }^{2}$ Department of Microbiology, Faculty of Veterinary Medicine, Kastamonu University, Kastamonu, Turkey ${ }^{3}$ Bandırma Vocational School, Bandırma Onyedi Eylül University, Bandırma, Balıkesir, Turkey
\end{abstract}

\section{Goncagul G., Gunaydin E., Cokal Y. \\ Antimicrobial susceptibility of bacteria isolated from goats with subclinical mastitis in the Southern Marmara region of Turkey \\ Summary}

The mastitis of dairy goats is a disease of economic importance worldwide and is mostly associated with bacterial infections. The aim of this study was to isolate the bacteria causing subclinical mastitis, and determine the susceptibility of some clinical isolates against several antimicrobial agents frequently used to control bacterial subclinical mastitis in dairy goats in the Southern Marmara Region. A total of 68 Saanen goats were used for this investigation and subclinical mastitis was determined by using California Mastitis Test. As a result of bacteriological analysis of milk samples, 30 different bacteria species have been identified and non-aureus staphylococci found to be the predominant bacteria species with the rate of $22.1 \%$. The species with the highest isolation rate among the isolates were Escherichia coli $(18.9 \%)$, Staphylococcus aureus (15.7\%), Streptococcus agalactiae (14.2\%) and Staphylococcus epidermidis $(\mathbf{7 . 9 \% )}$. The antimicrobial susceptibility of the high isolation rate species including Escherichia coli, Staphylococcus aureus, Streptococcus agalactiae, Staphylococcus epidermidis, Streptococcus uberis, Enterococcus faecalis, Staphylococcus haemolyticus and Mannheimia haemolytica to twelve antibiotics were determined by disc diffusion method. Bacterial strains analyzed showed highest sensitivity to ofloxacin $(87.9 \%)$, followed by cefuroxime $(85.8 \%)$ and cefazolin $(83.6 \%)$. In conclusion, subclinical mastitis still remains a problem in dairy goats, and for the elimination of subclinical mastitis, besides protective measures, determination of the bacteria causing mastitis and their antibiotic sensitivities should be a priority.

Keywords: goat, subclinic mastitis, bacteriology, antibiotic susceptibility

Mastitis, which results in a number of unfavorable health effects in the affected animals and leads to economic losses in farms, is the most prevalent mammary gland disease in goats (30), and it also has zoonotic importance (15). There are two forms of mastitis; clinical and subclinical (25). Subclinical mastitis (SCM) is often characterized by intramammary infection without clinical signs accompanied by an increase in somatic cell count (27). Clinical methods are useless in diagnosing the inflammation of the udder in SCM (10). Therefore, a broad spectrum of diagnostic techniques both on the farm and in the laboratory are required in SCM (25). Mastitis in goats is mainly subclinical, and it was reported that SCM is 15-40 times more prevalent than the clinical form (40). The prevalence of SCM in dairy goats was reported to be within the range of $5-45 \%(10,16)$.

SCM in goats was proved to be mainly of bacterial origin (5). Staphylococcus aureus, Pseudomonas aeruginosa, non-aureus staphylococci (NAS), Streptococcus agalactiae and other environmental pathogens were found to be the most common and most important bacterial species responsible for mastitis in goats $(19,28)$. Staphylococcus aureus was reported to be the cause of both acute and chronic mastitis that responded poorly to treatment. NAS was also found to be a major pathogen of SCM and clinical mastitis (43). Antibiotics are used to treat SCM. However, antimicrobial resistance in mastitis-causing pathogens due to the long-term usage of antibiotics was reported 
in previous studies $(1,36)$. Moreover, an irrational or incomplete treatment of infections was considered to be among the reasons for an antibiotic resistance (29). Due to delayed treatment and irrational usage of antibiotics, mastitis cases have been reported to become complex (17).

The diagnosis of SCM is based on the presence of inflammatory markers in the milk and microbiological isolation of the causative agent (16). Early diagnosis of SCM is vital because of changes taking place much earlier than they become apparent (10). The disease is usually undetectable, and so animals with SCM remain untreated. Therefore, in order to avoid persistent udder infection and the spread of the disease, early detection of elevated somatic cell count is very important (41). The scores of California mastitis test (CMT), which is currently used in the diagnosis of SCM, are directly related to the average somatic cell counts. A higher CMT score is indicative of a higher somatic cell concentration (26). CMT has been found to be efficient and reliable for diagnosis of SCM $(7,40)$. However, it has been also reported that California milk cell test and somatic cell counts on their own are not reliable methods in the identification of subclinical mastitis in the dairy goats and should be accompanied by microbiological tests (20). Although some other diagnostic tests such as surf field mastitis test and white side test were reported to be used in the diagnosis of SCM besides CMT, laborious bacteriological culture is still recommended to be a gold standard in the diagnosis of SCM (21). The objectives of the present study were to identify the major bacteria causing subclinical mastitis in dairy goats, assess SCM in lactating goats and determine the antimicrobial susceptibility patterns of the isolated bacteriae.

\section{Material and methods}

Study animals. This study was carried out in Southern Marmara Region of Turkey. Two hundred and fifty apparently healthy lactating Saanen goats were randomly selected from 20 Saanen goat herds. Herd size was between 10 and 50 . The herds were visited during morning hours and the samples of milk taken from each half of the udder were collected for CMT and bacteriological examination.

Milk sampling and California Mastitis Test. Milk samples from each half were collected aseptically and tested for SCM using CMT. The milk samples were transported to bacteriology laboratory in cold chain and then immediately cultured and/or stored at $4^{\circ} \mathrm{C}$ for a maximum of $24 \mathrm{~h}$ until cultured on standard bacteriological media. This screening test was conducted according to the standard procedure (34).

Culture and identification of bacteria. Each of the milk samples taken was initially inoculated into Fluid Thioglycollate Medium (BBL, 221196) and incubated at $37^{\circ} \mathrm{C}$ for $24 \mathrm{~h}$. Following incubation, a loopful of incubated sample was streaked on Blood agar plates (BBL, 297876) and EMB agar plates (BBL, 221355), and again incubated at $37^{\circ} \mathrm{C}$ for $24 \mathrm{~h}$. The colonies were assessed according to colony morphology and Gram color features. Identification of the isolates was performed using BBL Crystal (BectonDickinson, Sparks, USA) Gram positive and Gram negative ID system kits and its computer program.

Antimicrobial susceptibility test. ntimicrobial susceptibility test was applied to those with a high isolation rate among the isolated bacteria. A total of 89 isolates including Staphylococcus aureus, Streptococcus agalactiae, Mannheimia haemolytica, Escherichia coli, Enterococcus faecalis, Staphylococcus epidermidis, Streptococcus uberis and Staphylococcus haemolyticus were tested for antimicrobial susceptibility using the disc diffusion method according to the Clinical and Laboratory Standards Institute (8). The following antibiotic discs were used; ampicillin $(10 \mu \mathrm{g})$, erythromycin $(5 \mu \mathrm{g})$, enrofloxacin $(5 \mu \mathrm{g})$, gentamicin $(10 \mu \mathrm{g})$, kanamycin $(5 \mu \mathrm{g})$, amoxycillin + clavulanic $(30 \mu \mathrm{g})$, streptomycin $(10 \mu \mathrm{g})$, trimethoprim/sulfamethoxazole $(1.25 / 23.75 \mu \mathrm{g})$, tetracycline $(10 \mu \mathrm{g})$, ofloxacin $(5 \mu \mathrm{g})$, cefazolin $(30 \mu \mathrm{g})$, cefuroxime $(30 \mu \mathrm{g})$. (Oxoid, UK). Results were characterized as susceptible (S), intermediate (I) or resistant $(\mathrm{R})$ to specific antibiotics.

\section{Results and discussion}

A total of 250 apparently healthy randomly selected lactating Saanen goats from 20 Saanen goat herds were subjected to CMT and bacteriological examination to observe the prevalence of SCM and determine causative bacteria. CMT scores of milk samples and the prevalence of microorganisms isolated from the samples with single and mixed infection were presented in Table 1. In this study, the prevalence of SCM was found to be $27.2 \%$ (68/250) animal-level prevalence according to the CMT results. When our results were compared with the other studies, Pirzada et al (33), Islam et al (18), and Sarker and Samad (39) declared the rate of $38 \%, 36 \%, 49,9 \%$ positive results, respectively, which are higher than the rate in our study. While the rate of $20.4 \%$ positive result determined by McDougall et al (28) was found to be lower than our result, the rate of $27.2 \%$ in our study was found to be in line with the ranges between $5 \%$ and $30 \%$ determined by Contreras et al (10). Due to high sensitivity and specificity of CMT, some authors have evaluated CMT as a rapid, field-based test in the field $(7,40)$. It was reported that the specificity and sensitivity of the CMT were found to be $96 \%$ and $99 \%$, respectively (7).

Bacteriological culture of milk is still the gold standard method for detecting contagious mastitis outbreaks (14). In bacteriological analysis after CMT in this study, monomicrobial and mixed infections were found to be within the rate of $23.53 \%$ and $76.47 \%$, respectively (Tab. 1). The prevalence of all the microorganisms isolated from the studied samples was shown in Figure 1. E. coli, S. aureus, S. agalactiae, and S. epidermidis were isolated with the rates of $18.9 \%, 15.7 \%, 14.2 \%$ and $7.9 \%$, respectively. Also, the most frequent isolated bacteria were NAS with the rate of $22.1 \%$ in this study. In general, NAS has been determined to be the prevalent bacteria in the $\operatorname{SCM}(13,24,39)$. Sarker and Samad (39) reported mono microbial infection with the rate of 
Tab. 1. Results of CMT scores, and bacteriological isolation and identification

\begin{tabular}{|c|c|c|}
\hline $\begin{array}{l}\text { Sample } \\
\text { No }\end{array}$ & $\begin{array}{l}\text { CMT } \\
\text { score }\end{array}$ & Results of bacteriology and identification \\
\hline 1 & +++ & $\begin{array}{l}\text { Staphylococcus haemolyticus, Escherichia coli, } \\
\text { Staphylococcus aureus }\end{array}$ \\
\hline 2 & +++ & $\begin{array}{l}\text { Staphylococcus chromogenes, Escherichia coli, } \\
\text { Staphylococcus aureus }\end{array}$ \\
\hline 3 & +++ & $\begin{array}{l}\text { Enterococcus faecium, Escherichia coli, } \\
\text { Staphylococcus aureus }\end{array}$ \\
\hline 4 & +++ & Staphylococcus aureus \\
\hline 5 & ++ & Streptococcus agalactiae \\
\hline 6 & ++ & Escherichia coli, Streptococcus agalactiae \\
\hline 7 & ++ & Staphylococcus warneri, Streptococcus agalactiae \\
\hline 8 & ++ & Bacillus cereus, Staphylococcus epidermidis \\
\hline 9 & + & Cedecea lapagei, Acinetobacter Iwoffii \\
\hline 10 & ++ & Staphylococcus haemolyticus \\
\hline 11 & ++ & Streptococcus agalactiae, Enterococcus faecium \\
\hline 12 & ++ & Streptococcus agalactiae \\
\hline 13 & ++ & $\begin{array}{l}\text { Staphylococcus caprae, Bacillus pumilus, Bacillus } \\
\text { licheniformis }\end{array}$ \\
\hline 14 & + & Staphylococcus pasteuri \\
\hline 15 & ++ & Bacillus cereus, Streptococcus agalactiae \\
\hline 16 & + & Enterococcus faecium \\
\hline 17 & ++ & Streptococcus agalactiae \\
\hline 18 & + & Bacillus licheniformis, Pseudomonas fluorescens \\
\hline 19 & +++ & Enterococcus hirae, Staphylococcus aureus \\
\hline 20 & ++ & Streptococcus agalactiae, Staphylococcus caprae \\
\hline 21 & +++ & Staphylococcus aureus, Staphylococcus epidermidis \\
\hline 22 & +++ & Streptococcus agalactiae, Escherichia coli \\
\hline 23 & +++ & Streptococcus agalactiae, Staphylococcus aureus \\
\hline 24 & ++ & Escherichia coli, Enterococcus faecalis \\
\hline 25 & + & $\begin{array}{l}\text { Streptococcus bovis I (Group D), Pseudomonas } \\
\text { putida }\end{array}$ \\
\hline 26 & ++ & Staphylococcus haemolyticus, Enterococcus feacalis \\
\hline 27 & + & Cedecea lapagei, Acinetobacter Iwoffii \\
\hline 28 & +++ & Streptococcus agalactiae, Staphylococcus aureus \\
\hline 29 & ++ & Escherichia coli, Enterococcus faecalis \\
\hline 30 & ++ & $\begin{array}{l}\text { Escherichia coli, Enterococcus faecalis, } \\
\text { Staphylococcus epidermidis }\end{array}$ \\
\hline 31 & +++ & Streptococcus agalactiae, Staphylococcus aureus \\
\hline 32 & +++ & Escherichia coli, Staphylococcus aureus \\
\hline 33 & + & Staphylococcus simulans \\
\hline
\end{tabular}

\begin{tabular}{|c|c|c|}
\hline $\begin{array}{l}\text { Sample } \\
\text { No }\end{array}$ & $\begin{array}{l}\text { CMT } \\
\text { score }\end{array}$ & Results of bacteriology and identification \\
\hline 34 & ++ & Escherichia coli, Staphylococcus chromogenes \\
\hline 35 & + & Acinetobacter genomospecies, Escherichia coli \\
\hline 36 & ++ & Streptococcus dysgalactiae, Acinetobacter Iwoffii \\
\hline 37 & ++ & Streptococcus agalactiae \\
\hline 38 & + & Escherichia coli, Enterococcus faecalis \\
\hline 39 & ++ & Escherichia coli \\
\hline 40 & + & Escherichia coli \\
\hline 41 & +++ & Streptococcus agalactiae, Staphylococcus aureus \\
\hline 42 & ++ & Staphylococcus epidermidis, Streptococcus uberis \\
\hline 43 & ++ & $\begin{array}{l}\text { Staphylococcus xylosus, Bacillus pumilus, } \\
\text { Escherichia coli }\end{array}$ \\
\hline 44 & ++ & Escherichia coli, Staphylococcus caseolyticus \\
\hline 45 & +++ & Staphylococcus aureus \\
\hline 46 & +++ & Streptococcus agalactiae, Escherichia coli \\
\hline 47 & +++ & Escherichia coli, Staphylococcus aureus \\
\hline 48 & ++ & Staphylococcus epidermidis, Streptococcus uberis \\
\hline 49 & ++ & Streptococcus agalactiae \\
\hline 50 & +++ & Streptococcus uberis, Staphylococcus aureus \\
\hline 51 & + & Staphylococcus epidermidis \\
\hline 52 & + & Staphylococcus epidermidis, Streptococcus uberis \\
\hline 53 & + & Enterococcus faecalis, Staphylococcus epidermidis \\
\hline 54 & ++ & Staphylococcus epidermidis, Streptococcus uberis \\
\hline 55 & ++ & Staphylococcus caseolyticus, Proteus mirabilis \\
\hline 56 & ++ & Staphylococcus caseolyticus \\
\hline 57 & ++ & Streptococcus uberis, Staphylococcus epidermidis \\
\hline 58 & ++ & Staphylococcus aureus, Escherichia coli \\
\hline 59 & +++ & Staphylococcus aureus \\
\hline 60 & ++ & Mannheimia haemolytica, Escherichia coli \\
\hline 61 & +++ & Staphylococcus aureus, Escherichia coli \\
\hline 62 & ++ & Enterococcus faecalis, Escherichia coli \\
\hline 63 & +++ & $\begin{array}{l}\text { Staphylococcus aureus, Escherichia coli, } \\
\text { Streptococcus agalactiae }\end{array}$ \\
\hline 64 & +++ & Streptococcus agalactiae, Staphylococcus aureus \\
\hline 65 & ++ & Staphylococcus caseolyticus, Pseudomonas putida \\
\hline 66 & ++ & Mannheimia haemolytica, Escherichia coli \\
\hline 67 & + & Bacillus brevis, Staphylococcus intermedius \\
\hline 68 & +++ & $\begin{array}{l}\text { Staphylococcus xylosus, Bacillus pumilus, } \\
\text { Staphylococcus aureus }\end{array}$ \\
\hline
\end{tabular}

$76.27 \%$ and mixed infection with the rate of $16.95 \%$ in the infected milk samples. In a study conducted by Bochev and Russenova (6), the isolation rates of NAS and $S$. aureus, $80.2 \%$ and $19.8 \%$, respectively, were found to be higher than our isolation rates. Similarly, Ez Kotb et al (11) reported high isolation rates of NAS $(30 \%)$ and $S$. aureus $(25 \%)$ in their study. However, in a study conducted in Algeria, the isolation rates of NAS and $S$. aureus, $15.54 \%$ and $2.75 \%$, respectively, were lower than our results (7). In the studies conducted by

El Idrissi et al (12), Bergonier et al (4) and Contreras et al (9), the isolation rates of NAS were found to be $42.9 \%, 30.3 \%$ and $60-90 \%$, respectively. When those rates were compared with the rates in our study, the rate of NAS in our study was found to be low. Overall, staphylococci mammary infection in goats was due to the presence of these commensal germs of the mammary integument (39). The higher prevalence of intramammary infection with $S$. aureus could be a cause of a public health problem in food safety (37). In different studies, 


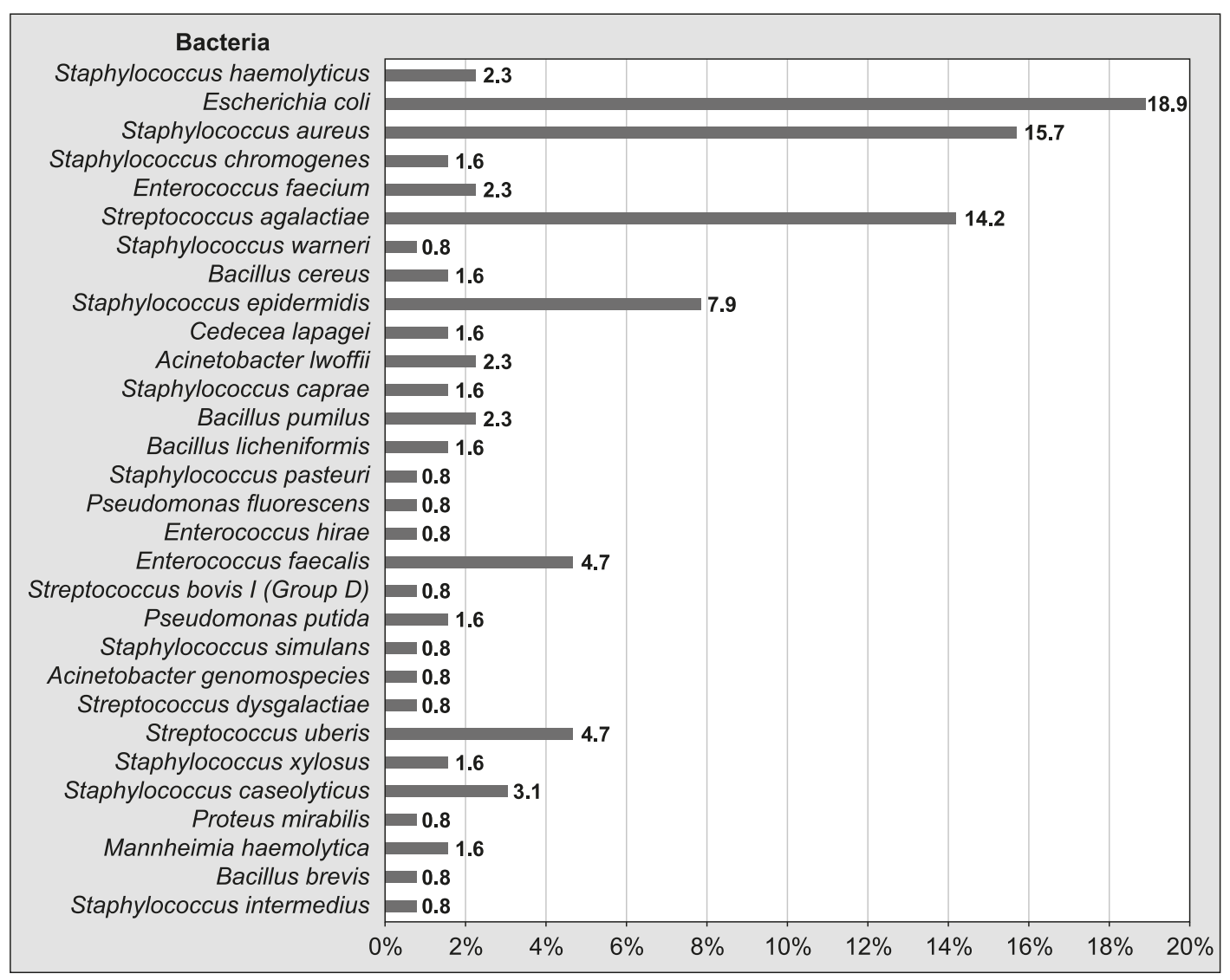

Fig. 1. Relative shares microorganisms causing SCM in goats variations were observed in the bacteriologic results of SCM since the variation in breed of goats, husbandry practice and agro climatic conditions affected the results (23). Another common isolate in our study was found to be $E$. coli, which is an environmental pathogen, as in the studies conducted by Ameh and Tari (2), and Sree Priya and Ayodhya (42). S. uberis (4.7\%), S. dysgalactiae $(0.8 \%)$ and $S$. bovis $(0.8 \%)$ were the other environmental pathogens isolated in our study. In a study conducted by Kostelic et al (22), while $S$. aureus was reported to be the common mastitic pathogen, Streptococcus D (6\%), Bacillus spp. (2\%), and E. coli $(2 \%)$ were declared to be the environmental pathogens. Similarly, the most common environmental pathogens were determined to be $S$. uberis, S. dysgalactiae, S. equinus, S. bovis, E. coli, Klebsiella spp., Citrobacter spp., Enterobacter spp., Pseudomonas spp., Serratia spp., and Proteus spp. in the previous studies $(34,35)$. The higher prevalence of contagious and environmental pathogens could be associated with poor sanitation arising from contamination of waste products like faeces and urine. If the hygienic precautions were not implemented, quite a large number of bacterial agents existing in environment could be a risk factor for mastitis (35).

Antibiotics are routinely used in the treatment of mastitis (3). However, an increase in the incidence of mastitis was reported to lead to an increase in unconscious and insufficient use of antibiotics resulting in the risk of antibiotic resistance (31). Therefore, accurate diagnosis and identification of the etiological agents causing mastitis and the use of effective antibiotics are necessary to determine treatment strategies. The susceptibility of 12 antibiotics against the mastitic pathogens isolated in this study was examined and the results were displayed in Table 2 . $S$. aureus, S. agalactiae, E. coli and S. uberis were not found to be $100 \%$ resistant to any of the tested antibiotics. The most prevalent bacteria in the study were

Tab. 2. Resistance patterns of bacteria isolated from milk of goats with SCM to 12 antibiotics

\begin{tabular}{|c|c|c|c|c|c|c|c|c|c|c|c|c|}
\hline \multirow{3}{*}{ Bacteria } & \multicolumn{12}{|c|}{ Percentage of resistance (\%) } \\
\hline & \multicolumn{12}{|c|}{ Antibiotics } \\
\hline & AMP & $\mathbf{E}$ & ENR & CN & K & AMC & S & SXT & TE & OFX & KZ & CXM \\
\hline Staphylococcus aureus (n: 20) & 5 & 15 & 10 & 0 & 5 & 10 & 5 & 0 & 25 & 10 & 0 & 0 \\
\hline Streptococcus agalactiae (n: 18) & 16.6 & 27.7 & 38.8 & 50 & 33.3 & 61.1 & 88.8 & 27.7 & 66.6 & 0 & 0 & 0 \\
\hline Mannheimia haemolytica (n: 2) & 0 & 100 & 0 & 50.0 & 50.0 & 0 & 50.0 & 0 & 50.0 & 0 & 0 & 0 \\
\hline Escherichia coli (n: 24) & 12.5 & 25.0 & 16.6 & 8.3 & 66.6 & 0.0 & 79.2 & 8.3 & 29.2 & 8.3 & 20.8 & 8.3 \\
\hline Enterococcus faecalis (n: 6) & 0.0 & 100 & 50.0 & 50.0 & 0.0 & 33.3 & 83.3 & 33.3 & 66.6 & 16.6 & 100 & 16.6 \\
\hline Staphylococcus epidermidis (n: 10) & 100 & 40.0 & 10.0 & 50.0 & 0.0 & 10.0 & 30.0 & 80.0 & 40.0 & 10.0 & 10.0 & 20.0 \\
\hline Streptococcus uberis (n: 6) & 83.3 & 66.6 & 33.3 & 66.6 & 66.6 & 33.3 & 33.3 & 83.3 & 16.6 & 33.3 & 0.0 & 50.0 \\
\hline Staphylococcus haemolyticus (n: 3) & 100 & 66.6 & 0.0 & 0.0 & 33.3 & 0.0 & 33.3 & 0.0 & 66.6 & 33.3 & 0.0 & 33.3 \\
\hline
\end{tabular}

Explanations: AMP - ampicillin, E - erythromycin, ENR - enrofloxacin, CN - gentamicin, K - kanamycin, AMC - amoxycillin + clavulanic, S - streptomycin, SXT - trimethoprim/sulfamethoxazole, TE - tetracycline, OFX - ofloxacin, KZ - cefazolin, CXM - cefuroxime 
found to be E. coli, and it was determined to be $100 \%$ sensitive to amoxycillin + clavulanic. Among the other antibiotics, ofloxacin $(87.9 \%)$, cefuroxime $(85.8 \%)$, cefazolin $(83.6 \%)$, amoxycillin + clavulanic $(81.5 \%)$, enrofloxacin $(80.1 \%)$, trimethoprim/sulfamethoxazole $(70.9 \%)$, gentamicin $(65.6 \%)$, kanamycin $(65 \%)$, ampicillin $(60.3 \%)$, tetracycline $(54.9 \%)$, streptomycin (49.6\%) and erythromycin (44.8\%) were found to be effective against mastitis causing pathogens. When 89 isolates were assessed for the percentage of antibiotic resistances against 12 antimicrobials, it was found that the highest resistance rate belonged to erythromycin with $55.2 \%$. The resistance pattern of all the resistant isolates to erythromycin might be attributed to the extensive and often injudicious use of erythromycin due to its good distribution in the mammary gland in treating mastitis (38). The higher sensitivity to ofloxacin, cefuroxime, cefazolin and amoxicillin + clavulanic in the present study could be due to very rare usage of those antibiotics in the treatment of mastitis. The sensitivity pattern recorded in the present study was in close accordance with those of Pal et al (32), who recorded that isolates were sensitive to amoxicillin and gentamicin but resistant to streptomycin. Sensitivity patterns of microbes are varied from region to region depending on ecological reasons, seasonal variations, unidentical microbial patterns, multiple drug resistance and area specificity (42). For the purpose of improving the effectiveness of the drug, bacteria susceptibility against the drug should be determined, and the results of the usage of specific antibiotics should be monitored. The data obtained are highly important, since the knowledge of local resistance patterns is fundamental for the design of effective treatment strategies. In conclusion, this study contributes to the improvement of critical decisions, correction of the wrong use of antibiotics, and preservation of public health and dairy industry.

\section{References}

1. Ali T., S. Rahman L., Zhang M., Shahid D., Han J., Gao S., Zhang P. L., Ruegg U., Saddique B., Han.: Characteristics and genetic diversity of multi-drug resistant extended-spectrum beta-lactamase (ESBL)-producing Escherichia coli isolated from bovine mastitis. Oncotarget 2017, 8, 90144 $-90163$.

2. Ameh J. A., Tari I. S.: Observations on the prevalence of caprine mastitis in relation to predisposing factors in Maiduguri. Small Ruminant Res.1999, $35,1-5$.

3. Barlow J.: Mastitis therapy and antimicrobial susceptibility: A multispecies review with a focus on antibiotic treatment of mastitis in dairy cattle. J. Mammary Gland Biol. Neopl. 2011, 16, 383-407.

4. Bergonier D., Blanc M. C., Fleury B., Lagriffoul G., Barillet F., Berthelot X.: Les mammites des ovins et des caprins laitiers: Étiologie, épidémiologie et contrôle. Renc. Rech. Rum.1997, 4, 251-260.

5. Bergonier D., Cremoux R. De, Rupp R., Lagriffoul G., Berthelot X.: Mastitis of dairy small ruminants. Vet. Res. 2003, 34, 689-716.

6. Bochev I., Russenova N.: Resistance of staphylococcus spp. Strains isolated from goats with subclinical mastitis. Bulg. J. Vet. Med. 2005, 8, 109-118.

7. Bourabah A., Ayad A., Boukraa L., Hammoudi S. M., Benbarek H.: Prevalence and etiology of subclinical mastitis in goats of the Tiaret Region, Algeria. Glob. Vet. 2013, 11, 604-608.

8. CLSI: Performance standards for antimicrobial susceptibility testing; twentieth informational supplement, CLSI document M100-S20, Clinical and Laboratory Standards Institute. Wayne, PA, USA 2011.
9. Contreras A., Sierra D., Corrales J. C., Sanchez A., Marco J.: Physiological threshold of somatic cell count and California mastitis test for diagnosis of caprine subclinical mastitis. Small Rumin. Res.1996, 21, 259-264.

10. Contreras A., Sierra D., Sánchez A., Corrales J. C., Marco J. C., Paape M. J., Gonzalo C.: Mastitis in small ruminants. Small Rumin. Res. 2007, 68, 145-153.

11. Ebtsam E. Z. K., El-Fattah A., Ola A., Azab A. M., Leil A. Z.: Ultrasonography, histopathological udder alterations and bacteriological investigations for diagnosis of mastitic goats. J. Appl. Vet. Sci. 2020, 5(2), 77-86.

12. El-Idrissi A. H., Benkirane A., Zardoune M.: Investigation of subclinical mastitis in dairy goat farming in Morocco. Rev. Elev. Méd. Vét. Pays Trop.1994, 47, 285-287.

13. Gebrewahid T. T., Abera B. H., Menghistu H. T.: Prevalence and etiology of Subclinical Mastitis, in Small ruminants of Tygray Regional State, North Ethiopia. Vet. World. 2012, 5, 103-109.

14. Gelasakis A. I., Mavrogianni V. S., Petridis I. G., Vasileiou N. G. C., Fthenakis $G$. C.: Mastitis in sheep - The last 10 years and the future of research. Vet. Microbiol. 2015, 181, 136-146.

15. Housawi F., Hatem M.: Studies on mastitis in female camel with special reference to brucellosis. J. Camel Sci. 2004, 1, 96-102.

16. Hristov K., Parvanov P., Pepovich R., Nikolov B.: Prevalence of mastitis and dynamics of health status mammary gland during lactation and dry period in goats. Scientific Works. Series C. Veterinary Medicine 2015, Vol. LXI, 163-167.

17. Hussain M., Yaqoob M., Riaz A., Umar S., Kashif J., Memon J., Shaheen S. Prevalence, bacteriology and antibiotic sensitivity profile of sub-clinical mastitis in goats in district Jhelum. Pak. J. Sci. 2017, 69, 240-245.

18. Islam M. R., Ahamed M. S., Alam M. S., Rahman M. M., Sultana T., Roh Y. S., Kim B.: Identification and antibiotic sensitivity of the causative organisms of sub-clinical mastitis in sheep and goats. Pak. Vet. J. 2012, 32, 179-182.

19. Jeph N. K., Chahar A., Tanwar R. K., Naresh M.: Clinico-therapeutic studies on clinical mastitis in goats (Capra hircus). Vet. Pract. 2013, 14, 359-360.

20. Karzis J., Donkin E. F., Petzer I. M.: The influence of intramammary antibiotic treatment, presence of bacteria, stage of lactation and parity in dairy goats as measured by the California Milk Cell Test and somatic cell counts. Onderstepoort J. Vet. Res. 2007, 74, 161-167.

21. Koop G., Islam M. N., Rahman M. M., Khatun M., Ferdous J., Sayeed M. A., Islam S., Ahaduzzaman M., Akter S., Mannan A., Hassan M. M.: Risk factors and therapy for goat mastitis in a hospital-based case-control study in Bangladesh. Prev. Vet. Med. 2016, 124, 52-57.

22. Kostelič A., Cergolj M., Tariba B., Rupič V., Benič M., Gantner V., Štokovič I.: Prevalence and aetiology of subclinical mastitis in goats. Ital. J. Anim. Sci. 2009, 8 (sup3), 134-136.

23. Kotb E., Gafer J.: Molecular Detection Of Toxins And Disinfectant Resistance Genes Among Staphylococcus aureus Isolated From Dairy Cattle In Egypt. J. Appl. Vet. Sci. 2020, 5, 35-45.

24. Kumar R., Gupta D. K., Bansal B. K., Singh S., Sharma S., Kumar A., Uppal $S$. $K$.: Prevalence, current antibiogram and risk factors associated with mastitis in dairy goats in Punjab. Int. J. Environ. Sci. Technol. 2016, 5, 4580-4593.

25. Leitner G., Merin U., Silanikove N., Ezra E., Chaffer M., Gollop N., Winkler M., Glickman A., Saran, A.: Effect of subclinical intramammary infection on somatic cell counts, NAGase activity and gross composition of goats' milk. J. Dairy Res. 2004, 71, 311-315.

26. Maisi P., Riipinen I.: Use of California Mastitis Test, N-acetyl- $\beta$ glucosaminidase, and antitrypsin to diagnose caprine subclinical mastitis. J. Dairy Sci.1988, 55, 309-314.

27. Marogna G., Pilo C., Vidili A., Tola S., Schianchi G., Leori S. G.: Comparison of clinical findings, microbiological results, and farming parameters in goat herds affected by recurrent infectious mastitis. Small Ruminant Res. 2012, 102, 74-83.

28. McDougall S., Supré K., De Vliegher S., Haesebrouck F., Hussein H., Clausen L., Prosser C.: Diagnosis and treatment of subclinical mastitis in early lactation in dairy goats. J. Dairy Sci. 2010, 93, 4710-4721.

29. Memon J., Kashif J., Yaqoob M., Liping W., Yang Y., Hongjie F.: Molecular characterization and antimicrobial sensitivity of pathogens from sub-clinical and clinical mastitis in Eastern China. Pak. Vet. J. 2013, 33, 170-174.

30. Merz A., Stephan R., Johler S.: Staphylococcus aureus isolates from goat and sheep milk seem to be closely relatedand difer from isolates detected from bovine milk. Front. Microbiol. 2016, 7, 1-7.

31. Oliver S. P., Murinda S. E.: Antimicrobial resistance of mastitis pathogens. Vet. Clin. North Am. Small Anim. Pract. 2012, 28, 165-185.

32. Pal B., Wadhwa D. R., Mandial R. K., Sharma M.: Acute and per-acute gangrenous mastitis in goats and its management. Intas Polivet. 2011, 12, 63-64.

33. Pirzada M., Malhi K. K., Kamboh A. A., Rind R., Abro S. H., Lakho S. A., Bhutto K. R., Huda N.: Prevalence of subclinical mastitis in dairy goats caused by bacterial species. J. Anim. Health Prod. 2016, 4, 55-59.

34. Ouinn P. J.,Carter M., Markey B. K., Carter G. R.: Clinical Veterinary Microbiology. Harcourt, Virginia 2011, p. 331-344. 
35. Radostits O. M., Gay C. C., Blood D. C., Hinchcliff K. W., Constable P. D. A Textbook of the diseases of Cattle, Sheep, Pigs, Goats and Horses. Veterinary Medicine 2007, 10, 1608-1609.

36. Rahman S., Ali T., Muhammad N., Umer T., Ahmad S., Ayaz S., Han B.: Characterization and mechanism of dissemination of extended spectrum beta lactamase producers Escherichia coli in food producing animals in Pakistan and China. Applied Sciences and Technology (IBCAST), $15^{\text {th }}$ Internat. Bhurban Conf. IEEE, Pakistan 2018.

37. Rainard P., Foucras G., Fitzgerald J. R., Watts J. L., Koop G., Middleton J. R. Knowledge gaps and research priorities in Staphylococcus aureus mastitis control. Transbound. Emerg. Dis. 2018, 65 (Suppl 1), 149-165.

38. Santos R. I., Zunino P. M., Gil A. D., Laport A., Hirigoyen D. J.: Antibiotic resistance of Staphylococcus aureus associated with subclinical and clinical mastitis in Uruguay during an eight-year period. Austral. J. Vet. Sci. 2017, 49, 191-194.
39. Sarker H., Samad M. A.: Udder-halve-wise comparative prevalence of clinical and subclinical mastitis in lactating goats with their bacterial pathogens and antibiotics sensitivity patterns in Bangladesh. Bangl. J. Med. 2011, 9, 137-143.

40. Shearer J. K., Harris J. B.: Mastitis in Dairy goats. Anim. Sci. Dept. Florida Coop. Ext. Serv. Inst. Food Agri. Sci. Univ. Fl. Gainesville USA 2003, 1-7.

41. Šiugždaitè J., Gabinaitiené A., Šiugžda R.: Antimicrobial resistance of pathogens from ewes'subclinical mastitis. Vet. Med. Zoot. 2016, 73, 122-127.

42. Sree Priya D., Ayodhya S.: Bacteriological and Antibiogram Studies Of Milk Samples Of Clinical Mastitis In Goats. J. Agric. Vet. Sci. 2016, 9, 33-35

43. Vanderhaeghen W., Piepers S., Leroy F., Van Coillie E., Haesebrouck F., De Vliegher S.: Identification, typing, ecology and epidemiology of coagulase negative staphylococci associated with ruminants. Vet. J. 2015, 203, 44-51.

Corresponding author: Assoc. Professor Gulsen Goncagul, PhD, DVM, University of Bursa Uludag, Mennan Pasinli Equine Vocational School 16000, Bursa, Turkey; e-mail: goncagul@uludag.edu.tr, gulgoncagulsen@gmail.com 